\title{
Spiroplasma lineolae sp. nov., from the Horsefly Tabanus lineola (Diptera: Tabanidae)
}

\author{
FRANK E. FRENCH, ${ }^{1 *}$ ROBERT F. WHITCOMB,${ }^{2}$ JOSEPH G. TULLY, ${ }^{3}$ PATRICIA CARLE, ${ }^{4}$ \\ JOSEPH M. BOVÉ, ${ }^{4}$ ROBERTA B. HENEGAR, ${ }^{2}$ JEAN R. ADAMS,${ }^{2}$ GAIL E. GASPARICH,${ }^{5} \dagger$ \\ AND DAVID L. WILLIAMSON ${ }^{6}$
}

\begin{abstract}
Department of Biology and Institute of Arthropodology and Parasitology, Georgia Southern University, Statesboro, Georgia 30460 ${ }^{1}$; Vegetable Laboratory, ${ }^{2}$ and Insect Biocontrol Laboratory, ${ }^{5}$ U.S. Department of Agriculture, Beltsville, Maryland 20705; Mycoplasma Section, Laboratory of Molecular Microbiology, National Institute of Allergy and Infectious Diseases, Frederick Cancer Research Facility, Frederick, Maryland 21702 ${ }^{3}$; Laboratoire de Biologie Cellulaire et Moléculaire, Institut Nationale de Recherche Agronomique, 33833 Villenave d'Ornon France ; and Department of Anatomical Sciences, State University of New York, Stony Brook, New York $11794^{6}$
\end{abstract}

\begin{abstract}
Spiroplasma strain TALS-2 ${ }^{\mathrm{T}}$ from the viscera of the striped horsefly, Tabanus lineola, collected in Georgia was serologically distinct from other Spiroplasma species, groups, putative groups, and subgroups. Light and electron microscopy of cells of strain TALS $-2^{\mathrm{T}}$ revealed helical motile cells surrounded only by a single cytoplasmic membrane. The organism grew in M1D and SP-4 liquid media. Growth also occurred in 1\% serum fraction medium and in conventional horse serum medium. Growth in liquid media was serum dependent. The strain passed through $220-\mathrm{nm}$ filter pores, but was retained in filters with $100-\mathrm{nm}$ pores. The optimum temperature for growth was $30^{\circ} \mathrm{C}$. Multiplication occurred at temperatures from 20 to $37^{\circ} \mathrm{C}$, with a doubling time at the optimum temperature of $5.6 \mathrm{~h}$ in M1D broth. Strain TALS-2 ${ }^{\mathrm{T}}$ catabolized glucose but hydrolyzed neither arginine nor urea. The guanine-plus-cytosine content of the DNA was $25 \pm 1$ mol\%. The genome size was $1,390 \mathrm{kbp}$. Six isolates serologically similar to strain TALS-2 ${ }^{\mathrm{T}}$ were obtained from the same host in coastal Georgia. Three strains closely related to strain TALS-2 ${ }^{\mathrm{T}}$ were isolated from the horsefly Poeciloderas quadripunctatus in Costa Rica. Strain TALS-2 ${ }^{\text {T }}$ (= ATCC 51749), a representative of group XXVII, is designated the type strain of a new species, Spiroplasma lineolae (Mollicutes: Entomoplasmatales).
\end{abstract}

The genus Spiroplasma (Mollicutes: Entomoplasmatales) (20, 21,30) consists of helical, wall-less prokaryotes associated with arthropods, particularly insects. In 1984, T. B. Clark and colleagues reported that tabanid flies (Diptera: Tabanidae) were a rich source of spiroplasmas (4). The strains reported in that paper and other strains discovered from tabanids since $(9,12$, $19,21,24-28,30)$ represent 11 spiroplasma groups. One of these groups, group VIII, contains three subgroups $(21,32)$. An intensive study has been mounted in Georgia to identify spiroplasmas in tabanids in the coastal plain region of that state $(5-7,16)$. Hundreds of isolates have been obtained, but most of these strains are serologically related to previously reported spiroplasma groups. The previously described groups obtained from tabanids include the following: group VIII, which includes three designated subgroups (subgroup VIII-1 [strain EA-1 ${ }^{\mathrm{T}}$; Spiroplasma syrphidicola], subgroup VIII-2 [strain DF-1 ${ }^{\mathrm{T}}$; Spiroplasma chrysopicola], and subgroup VIII-3 [strain TAAS-1] and is represented by strain TAAS-1 $(3,8,25$, 28); group XIV (strain EC-1 ${ }^{\mathrm{T}}$; Spiroplasma corruscae [9]); group XVIII (strain $\mathrm{TN}^{\mathrm{T}}{ }^{\mathrm{T}}$; Spiroplasma litorale [12]); and group XXIII (strain TG-1 ${ }^{\mathrm{T}}$; Spiroplasma gladiatoris [25]). An uncommon cluster from Georgia and Texas, group XXXII (represented by strain TABS- $2^{T}$ ), has recently been named Spiroplasma helicoides, and a more common cluster, group XXXIII (represented by strain TAUS-1 ${ }^{\mathrm{T}}$ ), has been named Spiroplasma tabanidicola (25). A few isolates from southern tabanids react in one-way serological tests with antisera to

\footnotetext{
* Corresponding author. Mailing address: Department of Biology, Georgia Southern University, Statesboro, GA 30460. Phone: (912) 681-5593. Fax: (912) 681-0845. E-mail: french@gsvms2.cc.gasou.edu.

$\uparrow$ Present address: Department of Biology, Towson State University, Towson, MD 21252.
}

group IV (strain $\mathrm{B} 31^{\mathrm{T}}$; Spiroplasma apis [15]) and group XXXI (strain HYOS-1 ${ }^{\mathbf{T}}$; Spiroplasma montanense [27]) (16). Another serological cluster from tabanids of the Georgia coastal plain has been proposed as group XXXIV, which is represented by strain B1901 (32). A fourth undesignated candidate subgroup of group VIII is represented by strain BARC 1357 (24). Another cluster, represented by BARC 2649 , represents a fifth undesignated subgroup of group VIII (32). This report concerns a cluster of serologically distinct isolates from the Georgia coastal plain which has been designated (32) group XXVII in the Spiroplasma group classification (23). Strain TALS-2 ${ }^{\mathrm{T}}$, the representative strain of this cluster (group XXVII), was isolated from the striped horsefly, Tabanus lineola, collected in coastal Georgia in July 1989. Since that time, six other Georgia isolates have been obtained that show major reactions with anti-TALS $-2^{\mathrm{T}}$ sera and that are presumed to be referrable to the TALS $-2^{\mathrm{T}}$ species cluster. This cluster is of special interest, since three strains from the horsefly Poeciloderas quadripunctatus from Costa Rica have proved to be very similar serologically to strain TALS $-2^{\mathrm{T}}$. In this communication, we present the results of a taxonomic study of strain TALS $-2^{\mathrm{T}}$, organized by the proposed (10) minimal requirements for assignment of binomial names to mollicutes. As a result of these studies, we describe group XXVII strain TALS $2^{\mathrm{T}}\left(=\right.$ ATCC $\left.51749^{\mathrm{T}}\right)$ as a member of a new species, Spiroplasma lineolae.

\section{MATERIALS AND METHODS}

Spiroplasma strains. The techniques used in the isolation of strain TALS-2 ${ }^{\mathrm{T}}$ from horseflies were essentially those described previously (14). Strain TALS $-2^{\mathrm{T}}$ was isolated by $\mathrm{F}$. E. French from the viscera of a female $T$. lineola fly collected near Statesboro, Ga., on 12 July 1989. Some of the genomic and serologic features of the organism have been described previously (32). Strain TALS-2 ${ }^{\mathrm{T}}$ was purified by conventional filtration cloning procedures (18). Representative strains of all previously recognized groups and subgroups (32), including the type strains of previously recognized species, were employed in this study. 
Culture media and cultivation techniques. Strain TALS $-2^{\mathrm{T}}$ was grown in primary culture at $30^{\circ} \mathrm{C}$ in M1D liquid medium (22) containing $500 \mathrm{U}$ of penicillin per $\mathrm{ml}$. A triply cloned strain derived from the original isolate was designated TALS $-2^{T}$ and used in all of the characterization studies. Other medium formulations used were SP-4 medium, serum-fraction broth supplemented with $1 \%$ bovine serum fraction, and conventional horse serum broth (22). A solid medium was prepared by adding 2.25 or $3 \%$ Noble agar (Difco Laboratories Detroit, Mich.) to the SP-4 formulation, and agar cultures were incubated at $30^{\circ} \mathrm{C}$ under both aerobic and anaerobic conditions (GasPak system; BBL Microbiology Systems, Cockeysville, Md.). Temperature requirements for growth were assessed by the method of Konai et al. (11).

Morphological studies. Cells of strain TALS $-2^{\mathrm{T}}$ in the logarithmic phase were examined at a magnification of $\times 1,250$ by dark-field microscopy. For electron microscopy, the strain was grown in approximately $3 \mathrm{ml}$ of broth and pelleted by centrifugation. The pelleted cells were fixed for $2 \mathrm{~h}$ in $3 \%$ glutaraldehyde, postfixed in $1 \%$ osmium tetroxide for $1 \mathrm{~h}$, dehydrated in acetone, embedded in Epon, sectioned, and stained with $2 \%$ aqueous uranyl acetate and Reynold's lead citrate.

Sterol requirements. Sterol requirements for growth were determined by a broth culture method in which we measured sustained growth either in serumfree broth, in serum-free broth supplemented with $0.04 \%$ Tween 80 , or in a medium containing fetal bovine serum supplements (17).

Biological and biochemical properties. The procedures used to study glucose fermentation and to detect arginine and urea hydrolysis have been described previously (12). Filtration characteristics were measured in M1D broth by techniques oullined previously (12)

Serological tests. Antiserum to strain TALS-2 ${ }^{\mathrm{T}}$ was raised in rabbits as previously described (31). Hyperimmune antisera to all previously established Spiroplasma species and groups were obtained from the reference collections at the Beltsville Agricultural Research Center and the National Institute of Allergy and Infectious Diseases laboratory in Frederick, Md. These antisera and strain TALS $-2^{\mathrm{T}}$ were tested in metabolism inhibition and deformation tests as previously described $(29,31)$

Genomic analysis. The guanine-plus-cytosine content of purified DNA of strain TALS $-2^{\mathrm{T}}$ was determined by buoyant density and melting temperature methods (1). The genome size was determined by pulsed-field gel electrophoresis (2)

\section{RESULTS AND DISCUSSION}

Cultural and morphological properties. Strain TALS $-2^{\mathrm{T}}$ grew well in M1D and SP-4 broth media and on solid media prepared from the SP-4 formulation. The strain also grew in conventional mycoplasma media containing horse serum or bovine serum fraction and was resistant to $500 \mathrm{U}$ of penicillin per $\mathrm{ml}$ in all of the medium formulations described above. Growth occurred over a temperature range of 20 to $37^{\circ} \mathrm{C}$, and optimum growth occurred at $30^{\circ} \mathrm{C}$. No growth was recorded during a 45 -day period at 15 or $41^{\circ} \mathrm{C}$. Strain TALS- $2^{\mathrm{T}}$ grew as diffuse, nondiscrete colonies on the usual "hard" agar medium (2.25\% agar) under either aerobic or anaerobic conditions. Increasing the agar concentration to $3 \%$ resulted in the formation of discrete colonies, which were small (diameter, 75 to $100 \mu \mathrm{m})$ and granular on plates incubated under anaerobic conditions (Fig. 1).

As determined by dark-field microscopy, logarithmic-phase cultures of strain TALS $-2^{\mathrm{T}}$ in SP-4 medium contained numerous long helical motile filaments, most of which had six or more turns. Unlike the cells of many spiroplasma strains, the cells of strain TALS-2 ${ }^{\mathrm{T}}$ retained their helical morphology under a variety of cultural conditions. As determined by electron microscopy, cells of this organism were filamentous with no evidence of a cell wall (Fig. 2). Most cells were about 200 to $300 \mathrm{~nm}$ in diameter and were surrounded by a single cytoplasmic membrane.

Sterol requirement. Strain TALS- $2^{\mathrm{T}}$ exhibited sustained growth through 23 serial 10 -fold dilutions in serum-containing medium. In two serum-free medium formulations, strain TALS $-2^{\mathrm{T}}$ occurred only in the first 10 -fold dilution, and the strain could not be successfully maintained beyond this passage level. These results indicate that there is a growth requirement for serum or sterol.

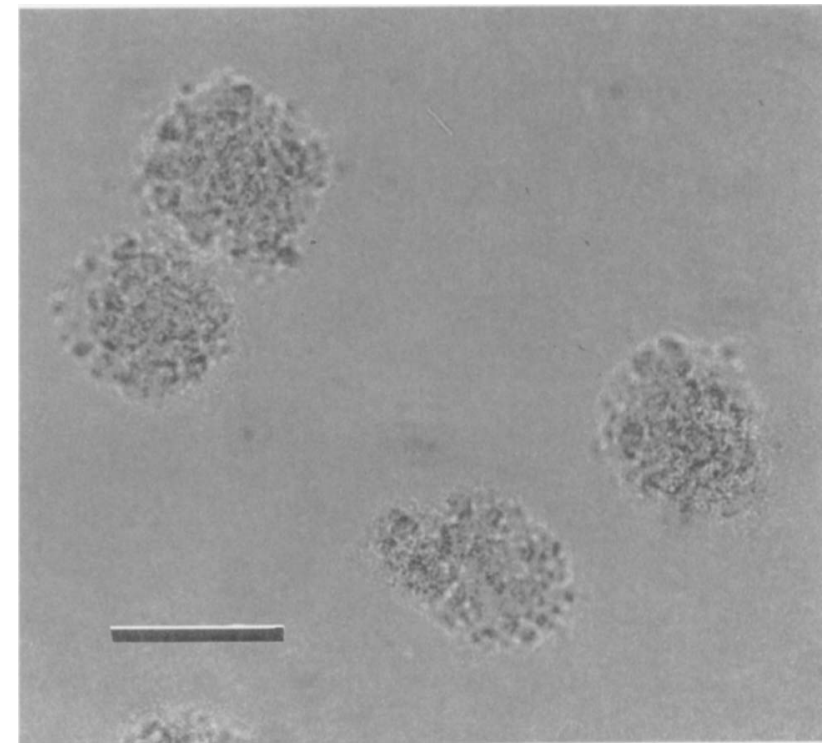

FIG. 1. Colonies of strain TALS-2 $2^{\mathrm{T}}$ on SP-4 medium containing $3 \%$ Noble agar after 14 days of anaerobic incubation at $30^{\circ} \mathrm{C}$. Bar $=100 \mu \mathrm{m}$.

Biochemical and biological properties. Strain TALS $-2^{\mathrm{T}}$ produced acid from glucose, but did not hydrolyze arginine or urea. Passage of broth cultures of strain TALS $-2^{\mathrm{T}}$ through 450 or 300 -nm-pore-size membrane filters reduced the viable cell titer by $1 \log _{10}$ unit, from $10^{8}$ to $10^{7}$ color-changing units $/ \mathrm{ml}$. The titer of a broth culture filtrate obtained after passage through a 220 -nm-pore-size membrane was reduced another 10 -fold, to $10^{6}$ color-changing units $/ \mathrm{ml}$; the 100 -nm-pore-size membrane filtrate was free of viable cells.

Serological tests. Metabolism inhibition and spiroplasma deformation tests indicated that strain TALS- $2^{\mathrm{T}}$ was unrelated serologically to representatives of previously established Spiroplasma groups or species. The serologic reactions of strain TALS $-2^{\mathrm{T}}$ are summarized in Table 1 . Strain PUP $-1^{\mathrm{T}}$ of Spiro-

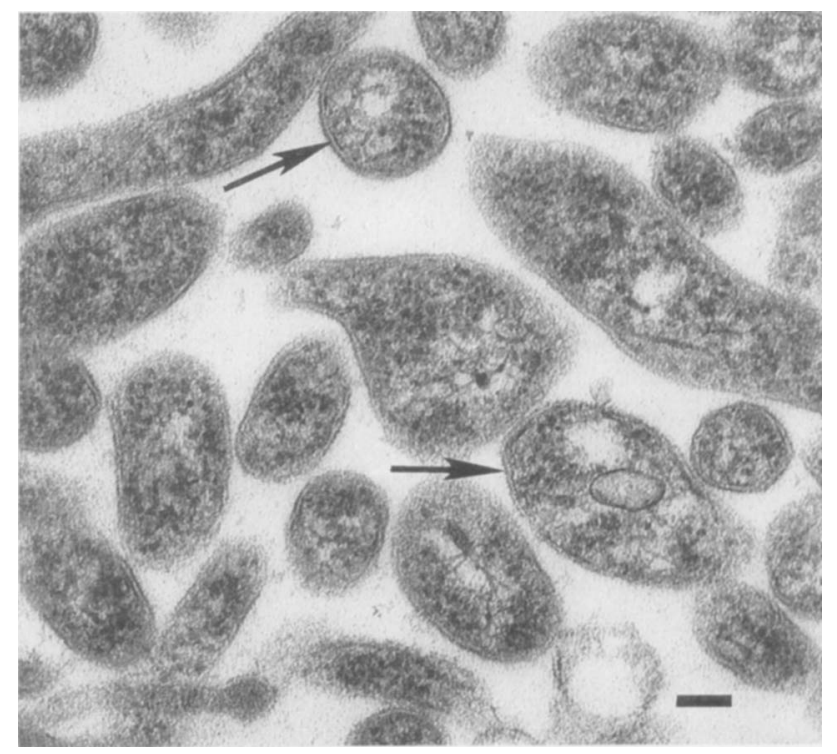

FIG. 2. Electron micrograph of cells of strain TALS $-2^{\mathrm{T}}$. Sections were stained with $2 \%$ aqueous uranyl acetate and Reynold's lead citrate. The arrows indicate the unit membrane. $\mathrm{Bar}=100 \mathrm{~nm}$. 
TABLE 1. Serological reactions and cross-reactions of strain TALS$2^{\mathrm{T}}$ in deformation and metabolism inhibition serological tests ${ }^{a}$

\begin{tabular}{|c|c|c|c|c|c|}
\hline \multirow{3}{*}{ Group } & \multirow{3}{*}{ Strain } & \multicolumn{4}{|c|}{ Titer in: } \\
\hline & & \multicolumn{2}{|c|}{$\begin{array}{c}\text { Spiroplasma } \\
\text { deformation test }\end{array}$} & \multicolumn{2}{|c|}{$\begin{array}{l}\text { Metabolism inhibition } \\
\text { test }\end{array}$} \\
\hline & & Antiserum $^{b}$ & Antigen $^{c}$ & Antiserum $^{b}$ & Antigen $^{c}$ \\
\hline $\mathrm{I}-5$ & LB-12 & $<20$ & $<20$ & 18 & $<18$ \\
\hline I-7 & N525 & $<20$ & $<20$ & 18 & $<18$ \\
\hline VII & $\mathrm{MQ}^{\mathrm{T}}{ }^{\mathrm{T}}$ & $<20$ & $<20$ & 54 & $<18$ \\
\hline XIV & $\mathrm{EC}-1^{\mathrm{T}}$ & 160 & $<20$ & $<18$ & $<18$ \\
\hline XIII & $\mathrm{Ar}-1343^{\mathrm{T}}$ & $<20$ & $<20$ & 18 & $<18$ \\
\hline XIX & PUP- $1^{T}$ & $<20$ & $<20$ & 1,458 & $<18$ \\
\hline $\mathrm{XX}$ & LD-1 ${ }^{\mathrm{T}}$ & $<20$ & $<20$ & 18 & $<18$ \\
\hline XXVI & PLHS-1 ${ }^{\mathrm{T}}$ & 40 & $<20$ & 54 & $<18$ \\
\hline XXVII & TALS-2 ${ }^{\mathrm{T}}$ & 320 & 320 & 1,458 & 1,458 \\
\hline XXIX & TIUS-1 & $<20$ & $<20$ & 18 & $<18$ \\
\hline All others & & $<20$ & $<20$ & $<18$ & $<18$ \\
\hline
\end{tabular}

${ }^{a}$ Antigen and antisera of strain TALS- $2^{\mathrm{T}}$ were tested in all heterologous combinations against all known and putative groups and subgroups. All reactions except those shown were negative.

${ }^{b}$ Reciprocal of the end point when strain TALS- $2^{\mathrm{T}}$ was used as the antigen.

${ }^{c}$ Reciprocal of the end point when antiserum to strain TALS- $2^{\mathrm{T}}$ was used.

plasma lampyridicola (group XIX) frequently shows strong one-way cross-reactions with antisera to representative strains of other groups; this was the case in the metabolism inhibition test, in which strain PUP- $1^{\mathrm{T}}$ cross-reacted with a titer of 1,458 to strain TALS $-2^{\mathrm{T}}$ antiserum but showed a titer of $<18$ in the reciprocal metabolism inhibition test.

Genome size and DNA base composition. The base composition (guanine-plus-cytosine content) of the DNA of TALS- ${ }^{\mathrm{T}}$ was $25 \pm 1 \mathrm{~mol} \%$. The genome size was $1,390 \mathrm{kbp}$.

Habitat. The strain described here was isolated from the viscera of the horsefly $T$. lineola. Six similar strains were isolated from the same host in coastal Georgia. Three strains with similar reactivities were isolated from the tabanid fly $P$. quadripunctatus in Costa Rica. These facts, the inability of the strain to multiply at $15^{\circ} \mathrm{C}$, and the absence of the organism in hundreds of isolates from France (13) and North America north of latitude $35^{\circ} \mathrm{N}$ suggest that strains related to strain TALS $-2^{\mathrm{T}}$ may occur only in warm climates of the New World. Strain TALS-2 ${ }^{\mathrm{T}}$ and the six related Georgia isolates were all obtained from $T$. lineola collected at three sites in Bulloch County, Ga., during July, September, and October in 1989 to 1991 (7). From 34 other $T$. lineola individuals collected concurrently, 19 isolates of other spiroplasmas were obtained. Isolates related to strain TALS $-2^{T}$ were relatively rare, representing only about $4 \%$ ( 7 of 181 ) of the isolates obtained from $T$. lineola from Bulloch County, $\mathrm{Ga}$. No isolates of strain TALS $-2^{\mathbf{T}}$ were among 227 isolates from other tabanids from the southeastern United States, including one Chlorotabanus species, eight Chrysops species, two Hybomitra species, one Leucotabanus species, and 15 Tabanus species. Like most mollicutes cultivated from insects, strain TALS $-2^{\mathrm{T}}$ was isolated from the host viscera and is not known to be pathogenic for its host.

The properties described here for strain TALS $-2^{\mathrm{T}}$ fulfill the proposed criteria (10) for species of the class Mollicutes, including the absence of a cell wall, filterability, and penicillin resistance. The inability of this strain to utilize urea and its helicity and motility place this organism in the family Spiroplasmataceae in the order Entomoplasmatales (20). Finally, the serologic comparison of group XXVII strain TALS-2 ${ }^{\mathrm{T}}$ to representatives of other Spiroplasma species, groups, and sub- groups demonstrated the uniqueness of the strain. We therefore propose the name Spiroplasma lineolae for this organism. The taxonomic description below summarizes the properties of this organism.

Description of Spiroplasma lineolae sp. nov. Spiroplasma lineola (lin.e.o'la. M.L. n. lineola, a species of tabanid fly; M.L. gen. $n$. lineolae, of $T$. lineola, from which the organism was isolated).

Cells are helical, motile filaments that vary from 200 to 300 $\mathrm{nm}$ in diameter. Cells lack true cell walls. Colonies on solid medium containing 3\% Noble agar are small and granular and never have a "fried-egg" appearance.

Chemoorganotroph. Acid is produced from glucose. Does not hydrolyze arginine or urea.

Cholesterol or serum is required for growth.

The temperature range for growth is 20 to $37^{\circ} \mathrm{C}$, and optimum growth occurs at $30^{\circ} \mathrm{C}$. The doubling time at the optimum temperature in M1D broth is $5.6 \mathrm{~h}$.

Serologically distinct from previously established Spiroplasma species. Isolated from viscera of the tabanid fly $T$. lineola. Pathogenicity for insects has not been determined.

The guanine-plus-cytosine content of the DNA is $25 \pm 1$ mol\%, and the genome size is $1,390 \mathrm{kbp}$.

The type strain is TALS-2 (= ATCC 51749).

\section{ACKNOWLEDGMENTS}

We thank Jeffrey L. Buller, Georgia Southern University, Statesboro, for his advice concerning the specific epithet. We also thank Mary Fenton for assistance with the electron microscopy.

This research was supported in part by the Georgia Southern University Faculty Research Committee.

\section{REFERENCES}

1. Carle, P., C. Saillard, and J. M. Bové. 1983. Determination of guanine plus cytosine content of DNA, p. 301-308. In S. Razin and J. G. Tully (ed.), Methods in mycoplasmology, vol. 1. Academic Press, New York, N.Y.

2. Carle, P., F. Laigret, J. G. Tully, and J. M. Bové. 1995. Heterogeneity of genome sizes within the genus Spiroplasma. Int. J. Syst. Bacteriol. 45:178181.

3. Clark, T. B. 1982. Spiroplasmas: diversity of arthropod reservoirs and hostparasite relationships. Science 217:57-59.

4. Clark, T. B., R. V. Peterson, R. F. Whitcomb, R. B. Henegar, K. J. Hackett, and J. G. Tully. 1984. Spiroplasmas in the Tabanidae. Isr. J. Med. Sci. 20:1002-1005.

5. French, F. E., R. F. Whitcomb, D. V. Hagan, J. A. Rafter, M. Konai, and E. A. Clark. 1992. Dynamics of Spiroplasma infections in tabanid (Diptera: Tabanidae) flies, laboratory transmission, and in vitro tests. IOM Lett. 2:114.

6. French, F. E., R. F. Whitcomb, J. G. Tully, K. J. Hackett, E. A. Clark, R. B. Henegar, and D. L. Rose. 1990. Tabanid spiroplasmas of the southeast USA: new groups, and correlation with host life history strategy. Zentralbl. Bakteriol. Int. J. Med. Microbiol. 20:919-921.

7. French, F. E., R. F. Whitcomb, J. G. Tully, D. L. Williamsom, and R. B. Henegar. 1996. Spiroplasmas of Tabanus lineola. IOM Lett. 4:211-212.

8. Gasparich, G. E., C. Saillard, E. A. Clark, M. Konai, F. E. French, J. G. Tully, K. J. Hackett, and R. F. Whitcomb. 1993. Serologic and genomic relatedness of group VIII and group XVII spiroplasmas and subdivisions of spiroplasma group VIII. Int. J. Syst. Bacteriol, 43:338-341.

9. Hackett, K. J., R. F. Whitcomb, F. E. French, J. G. Tully, G. E. Gasparich, D. L. Rose, P. Carle, J. M. Bové, R. B. Henegar, T. B. Clark, M. Konai, E. A. Clark, and D. L. Williamson. 1996. Spiroplasma corruscae sp. nov., a new species from a firefly beetle (Coleoptera: Lampyridae) and tabanid flies (Diptera: Tabanidae). Int. J. Syst. Bacteriol. 46:947-950.

10. International Committee on Systematic Bacteriology Subcommittee on the Taxonomy of Mollicutes. 1995. Revised minimum standards for descriptions of new species of the class Mollicutes (division Tenericutes). Int. J. Syst. Bacteriol. 45:605-612.

11. Konai, M., E. A. Clark, M. Camp, and R. F. Whitcomb. 1996. Temperature ranges and growth optima of Spiroplasma (Mollicutes: Spiroplasmataceae) species. Curr. Microbiol. 32:314-319.

12. Konai, M., R. F. Whitcomb, F. E. French, J. G. Tully, D. L. Rose, P. Carle, J. M. Bové, K. J. Hackett, R. B. Henegar, T. B. Clark, and D. L. Williamson. 1997. Spiroplasma litorale sp. nov. from tabanid flies (Tabanidae: Diptera) in the southeastern United States. Int. J. Syst. Bacteriol. 47:359-362.

13. Le Goff, F., I. Humphery-Smith, M. Leclercq, and C. Chastel. 1991. Spiro- 
plasmas from European Tabanidae. Med. Vet. Entomol. 5:143-144

14. Markham, P. G, T. B. Clark, and R. F. Whitcomb. 1983. Culture techniques for spiroplasmas from arthropods, p. 217-223. In J. G. Tully and S. Razin (ed.), Methods in mycoplasmology, vol. 2. Academic Press, New York, N.Y.

15. Mouchès, C., J. M. Bové, J. G. Tully, D. L. Rose, R. E. McCoy, P. Carle, P. Junca, M. Garnier, and C. Saillard. 1983. Spiroplasma apis, a new species from the honey bee Apis mellifera. Ann. Inst. Pasteur Microbiol. 134:383397.

16. Moulder, R. W., F. E. French, R. F. Whitcomb, and R. Henegar. 1996. Spiroplasma carriage in two spring tabanid flies. IOM Lett. 4:200-201.

17. Rose, D. L., J. G. Tully, J. M. Bové, and R. F. Whitcomb. 1993. A test for measuring growth responses of mollicutes to serum and polyoxyethylene sorbitan. Int. J. Syst. Bacteriol. 43:527-532.

18. Tully, J. G. 1983. Cloning and filtration techniques for mycoplasmas, p. 173-177. In S. Razin and J. G. Tully (ed.), Methods in mycoplasmology, vol. 1. Academic Press, New York, N.Y.

19. Tully, J. G., and R. F. Whitcomb. 1991. The genus Spiroplasma, p. 19601980. In A. Balows, H. G. Trüper, M. Dworkin, W. Harder, and K.-H. Schleifer (ed.), The prokaryotes, 2nd ed., vol. 2. Springer-Verlag, New York, N.Y.

20. Tully, J. G., J. M. Bové, F. Laigret, and R. F. Whitcomb. 1993. Revised taxonomy of the class Mollicutes: proposed elevation of a monophyletic cluster of arthropod-associated mollicutes to ordinal rank (Entomoplasmatales ord. nov.), with provision for familial rank to separate species with nonhelical morphology (Entomoplasmataceae fam. nov.) from helical species (Spiroplasmataceae), and emended descriptions of the order Mycoplasmatales, family Mycoplasmataceae. Int. J. Syst. Bacteriol. 43:378-385.

21. Tully, J. G., D. L. Rose, E. Clark, P. Carle, J. M. Bové, R. B. Henegar, R. F. Whitcomb, D. E. Colflesh, and D. L. Williamson. 1987. Revised group classification of the genus Spiroplasma (class Mollicutes), with proposed new groups XII to XXIII. Int. J. Syst. Bacteriol. 37:357-364.

22. Whitcomb, R. F. 1983. Culture media for spiroplasmas, p. 147-158. In S. Razin and J. G. Tully (ed.), Methods in mycoplasmology, vol. 1. Academic Press, New York, N.Y.

23. Whitcomb, R. F., J. M. Bové, T. A. Chen, J. G. Tully, and D. L. Williamson.
1987. Proposed criteria for an interim serogroup classification for members of the genus Spiroplasma (class Mollicutes). Int. J. Syst. Bacteriol. 37:82-84.

24. Whitcomb, R. F., F. E. French, J. G. Tully, P. Carle, R. B. Henegar, K. J. Hackett, J. Adams, and D. L. Williamson. Spiroplasma species, groups, and subgroups from North American Tabanidae. Curr. Microbiol., in press.

25. Whitcomb, R. F., F. E. French, J. G. Tully, G. Gasparich, D. L. Rose, P Carle, J. M. Bové, R. B. Henegar, M. Konai, K. J. Hackett, J. Adams, T. B. Clark, and D. L. Williamson. 1997. Spiroplasma chrysopicola sp. nov., Spiroplasma gladiatoris sp. nov., Spiroplasma helicoides sp. nov., and Spiroplasma tabanidicola sp. nov., from tabanid (Diptera: Tabanidae) flies. Int. J. Syst Bacteriol. 47:713-719.

26. Whitcomb, R. F., F. E. French, J. G. Tully, G. E. Gasparich, J. M. Bové, P Carle, E. A. Clark, and R. B. Henegar. 1992. Tabanid spiroplasma serovars. IOM Lett. 2:115.

27. Whitcomb, R. F., F. E. French, J. G. Tully, D. L. Rose, P. M. Carle, J. M Bové, R. B. Henegar, M. Konai, K. J. Hackett, J. R. Adams, and D. L. Williamson. 1997. Spiroplasma montanense sp. nov., from Hybomitra horse flies at northern latitudes in North America. Int. J. Syst. Bacteriol. 47:720723.

28. Whitcomb, R. F., G. E. Gasparich, F. E. French, J. G. Tully, D. L. Rose, P. Carle, J. M. Bové, R. B. Henegar, M. Konai, K. J. Hackett, J. R. Adams, T. B. Clark, and D. L. Williamson. 1996. Spiroplasma syrphidicola sp. nov., from a syrphid (Diptera: Syrphidae) fly. Int. J. Syst. Bacteriol. 46:797-801.

29. Williamson, D. L., J. G. Tully, and R. F. Whitcomb. 1979. Serological relationships of spiroplasmas as shown by combined deformation and metabolism inhibition tests. Int. J. Syst. Bacteriol. 29:345-351.

30. Williamson, D. L., J. G. Tully, and R. F. Whitcomb. 1989. The genus Spiro plasma, p. 71-111. In R. F. Whitcomb and J. G. Tully (ed.), The mycoplasmas, vol. 5. Academic Press, New York, N.Y.

31. Williamson, D. L., R. F. Whitcomb, and J. G. Tully. 1979. The spiroplasma deformation test, a new serological method. Curr. Microbiol. 1:203-207.

32. Williamson, D. L., R. F. Whitcomb, J. G. Tully, G. E. Gasparich, D. L. Rose, P. Carle, J. M. Bové, K. J. Hackett, R. B. Henegar, M. Konai, C. Chastel, and F. E. French. Revised group classification of the genus Spiroplasma. Submitted for publication. 